\title{
CREB3L4 wt Allele
}

National Cancer Institute

\section{Source}

National Cancer Institute. CREB3L4 wt Allele. NCI Thesaurus. Code C52531.

Human CREB3L4 wild-type allele is located in the vicinity of 1q21.3 and is approximately 6 $\mathrm{kb}$ in length. This allele, which encodes CAMP responsive element-binding protein 3-like protein 4, plays a role in the mediation of transcription in response to cyclic AMP. 